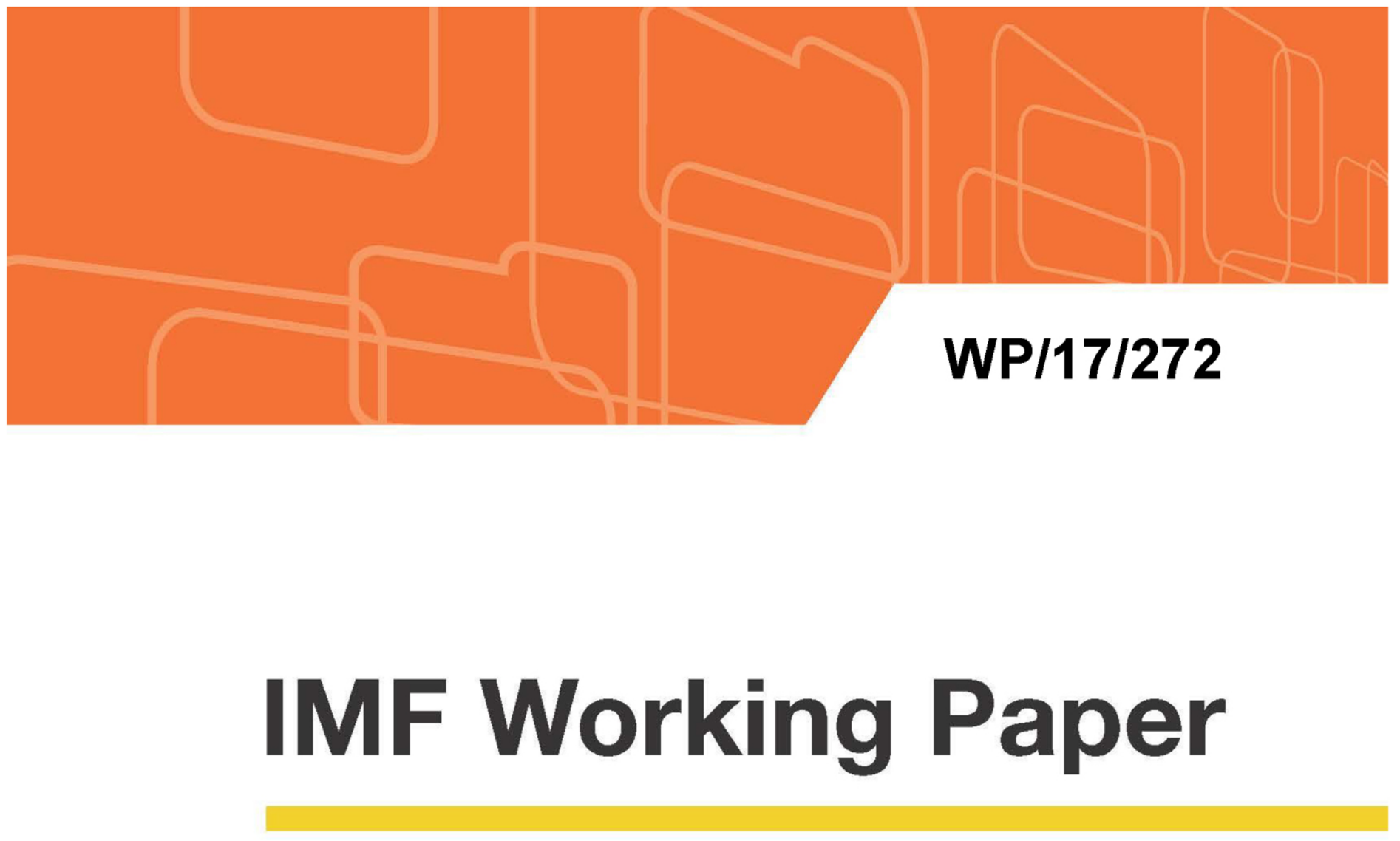

\title{
Reassessing the Perimeter of Government Accounts in China
}

by Rui C. Mano and Phil Stokoe

IMF Working Papers describe research in progress by the author(s) and are published to elicit comments and to encourage debate. The views expressed in IMF Working Papers are those of the author(s) and do not necessarily represent the views of the IMF, its Executive Board, or IMF management.

$$
\text { I N T E R N A T I O N A L M O N E T A R Y F U N D }
$$




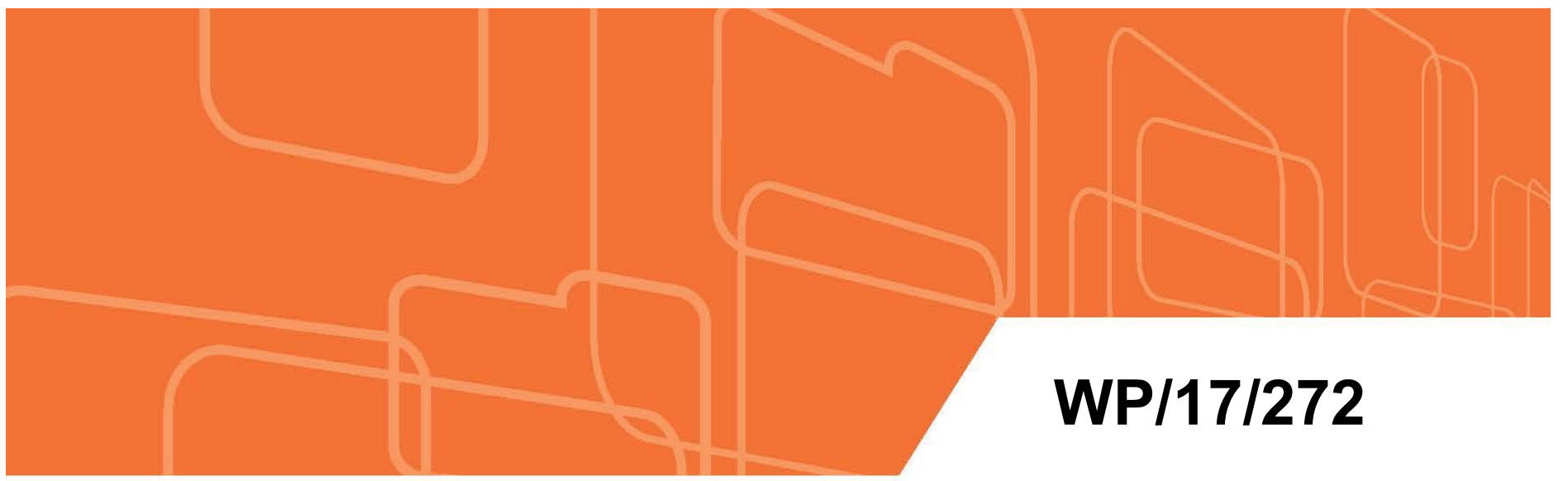

\section{IMF Working Paper}

\section{Reassessing the Perimeter of Government Accounts in China}

by Rui C. Mano and Phil Stokoe

IMF Working Papers describe research in progress by the author(s) and are published to elicit comments and to encourage debate. The views expressed in IMF Working Papers are those of the author(s) and do not necessarily represent the views of the IMF, its Executive Board, or IMF management.

$$
\text { I N T E R N A T I O N A L M O N E T A R Y F U N D }
$$




\title{
IMF Working Paper
}

Asia Pacific Department

\section{Reassessing the Perimeter of Government Accounts in China \\ Prepared by Rui C. Mano and Phil Stokoe*}

Authorized for distribution by James Daniel

November 2017

\section{IMF Working Papers describe research in progress by the author(s) and are published to elicit comments and to encourage debate. The views expressed in IMF Working Papers are those of the author(s) and do not necessarily represent the views of the IMF, its Executive Board, or IMF management.}

\begin{abstract}
China's official general government accounts do not include off-budget quasi-fiscal spending unlike the IMF's augmented government accounts. This paper argues that the broader concept of augmented government remains relevant despite recent positive measures to separate off-budget units from the government. In fact, new avenues to finance public infrastructure, such as Special Construction Funds and Government Guided Funds, have emerged and this paper re-defines the perimeter of augmented government to include them. Finally, concrete steps for improving China's fiscal accounts are put forward. If these steps are taken, the perimeter of general government would expand relative to official statistics but would likely be narrower than where augmented aggregates place it.
\end{abstract}

JEL Classification Numbers: H1, H6, H7

Keywords: Government Statistics, Fiscal Risks, Local Government Finance, China

Author's E-Mail Address: rmano@imf.org; pstokoe@imf.org;

\footnotetext{
* International Monetary Fund. We thank Miguel Angelo Alves, Serkan Arslanalp, James Daniel, Paolo Dudine, Sonali Jain-Chandra, Marialuz Moreno Badia, Markus Rodlauer and Zaijin Zhan for helpful comments and Tlek Zeinullayev and Daniel Tak Yan Law for research assistance. We also thank Daisy Lu for providing data compiled by Moody's. Remaining mistakes are our own.
} 


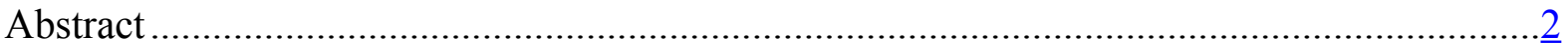

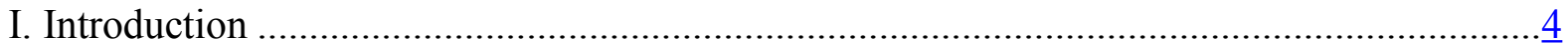

II. A Framework for Establishing the Perimeter of Government Accounts and China's Official Government Statistics........................................................................................

III. Revisiting Augmented Government Estimates ............................................................

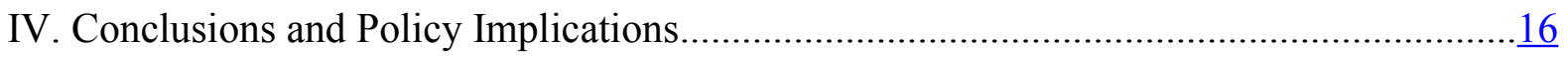

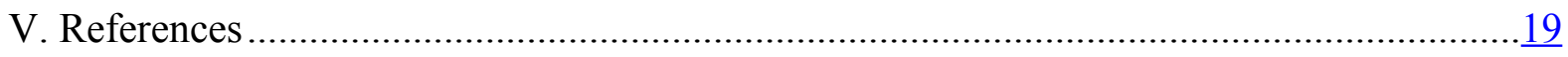

Appendix 1: Case Studies - Classification of Selected LGFVs …………………………....20

A. Tianjin Rail Transit Group Ltd ……………………………………………...20

B. Zhenjiang Transportation Industry Group Co Ltd. ................................................21

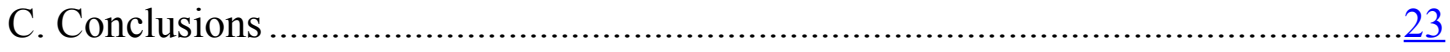

Appendix 2: Detailed Assumptions Behind the Inclusion of SCFs and GGFs ........................25 


\section{INTRODUCTION}

China's official government accounts do not capture a large amount of fiscal spending delivered through off-budget units. China's official fiscal data is based on the authorities' definition of national government that includes only budgetary units. However, the government has relied heavily on off-budget stimulus since the global financial crisis (GFC).

Hence, IMF staff created the concept of "augmented" fiscal aggregates. ${ }^{1}$ Augmented fiscal aggregates crucially add net spending and debt of local government financing vehicles (LGFV) to the government's official numbers. These off-budget vehicles bypassed the strict ban on official local government borrowing inscribed in the 1994 budget law. Augmented fiscal aggregates are believed to reflect more accurately China's fiscal stance and fiscal risks.

The Chinese authorities are aware of the fiscal risks implied by off budget borrowing and undertook reforms to constrain it. A new budget law (effective in 2015) allowed local governments (LG) to borrow officially, brought on-budget a large amount of LGFV debt, and reiterated the ban on off-budget borrowing. Many other measures have been undertaken since. These efforts aim to "open the front door while closing the back door", by bringing fiscal spending on-budget and closing off-budget financing channels.

\section{This paper re-visits the concept of augmented government in light of recent} developments and policy measures. Are augmented aggregates still relevant, despite the authorities' recent efforts to restrict off-budget LG borrowing? Does the concept of augmented government need to be revised and its perimeter re-assessed?

The main findings are:

- China's official statistics use a narrower perimeter of general government than what is recommended by international statistical guidelines. Crucially, China's government statistics include no extra-budgetary units, that is, units that are legally separate from the government but that perform government functions. Such units are included in government finance statistics of many other major economies.

- $\quad$ Although progress has been made to legally separate off-budget units from the government, such units appear to not have been de facto separated from the government.

- $\quad$ Thus, using augmented aggregates in macro surveillance remains appropriate, until a case-by-case review of off-budget units takes place. Such work requires detailed data that are not publicly available.

- $\quad$ At the same time, new vehicles for off-budget spending have emerged and an expansion of the perimeter of augmented aggregates is warranted.

\footnotetext{
${ }^{1}$ See NAO (2011), (2013) for official estimates of off-budget LG debts. Also, see Box 1 of IMF (2013) and Zhang and Barnett (2014) for early IMF estimates and Bai and others (2016) for a more recent study.
} 
- $\quad$ Finally, concrete steps for improving monitoring, control and transparency of fiscal accounts are put forward.

The Chinese authorities disagree with the use of augmented fiscal aggregates. The authorities' views are that the new budget law, effective in 2015, and the concurrent verification of local government debts, clearly stipulated that LGFVs are private entities fully independent from the government. Thus, LGFV debt is not a government obligation. The same applies to PPPs, special construction funds and government guided funds. Hence, they contend that augmented fiscal statistics are misleading and not in accordance with Chinese law.

The paper is organized as follows: Section II outlines the international standard for establishing the perimeter of government and China's own official definition of government; Section III discusses recent developments and re-assesses the perimeter of augmented government accounts in China; Section IV concludes.

\section{A FRAMEWORK FOR ESTABLISHING THE PERIMETER OF GOVERNMENT ACCOUNTS AND CHINA'S OFFICIAL GOVERNMENT STATISTICS}

Effective surveillance of fiscal developments requires a clear definition of "government" and "the wider public sector". The IMF has long aligned its thinking on these issues with the System of National Accounts (SNA) beginning with the Manual on Government Finance Statistics 1986 (GFSM 86) and in the more recent Government Finance Statistics Manual 2001 (GFSM 2001) and its 2014 update (GFSM 2014).

According to international statistical manuals, the general government includes central, state and local government tiers, as well as social security funds. Within the central, state and local government tiers, there are often what GFSM 86 refers to as decentralized agencies, and GFSM 2001/2014 as extrabudgetary units. These units, which may have considerable autonomy and own revenues, are nevertheless also considered part of the general government sector.

Beyond the general government, the wider public sector includes nonfinancial and financial corporations. Public nonfinancial corporations include entities engaged in a very wide range of activities, including utility companies, public transport companies, mining and manufacturing enterprises. Public financial corporations include entities engaged in financial intermediation and associated activities, this includes the monetary authorities / central bank, other deposit takers (such as public sector banks), as well as insurance corporations, pension funds, development banks and financial supervisory agencies.

Figure 1 presents a typical structure of general government and the wider public sector. 
Figure 1. Structure of the Public Sector

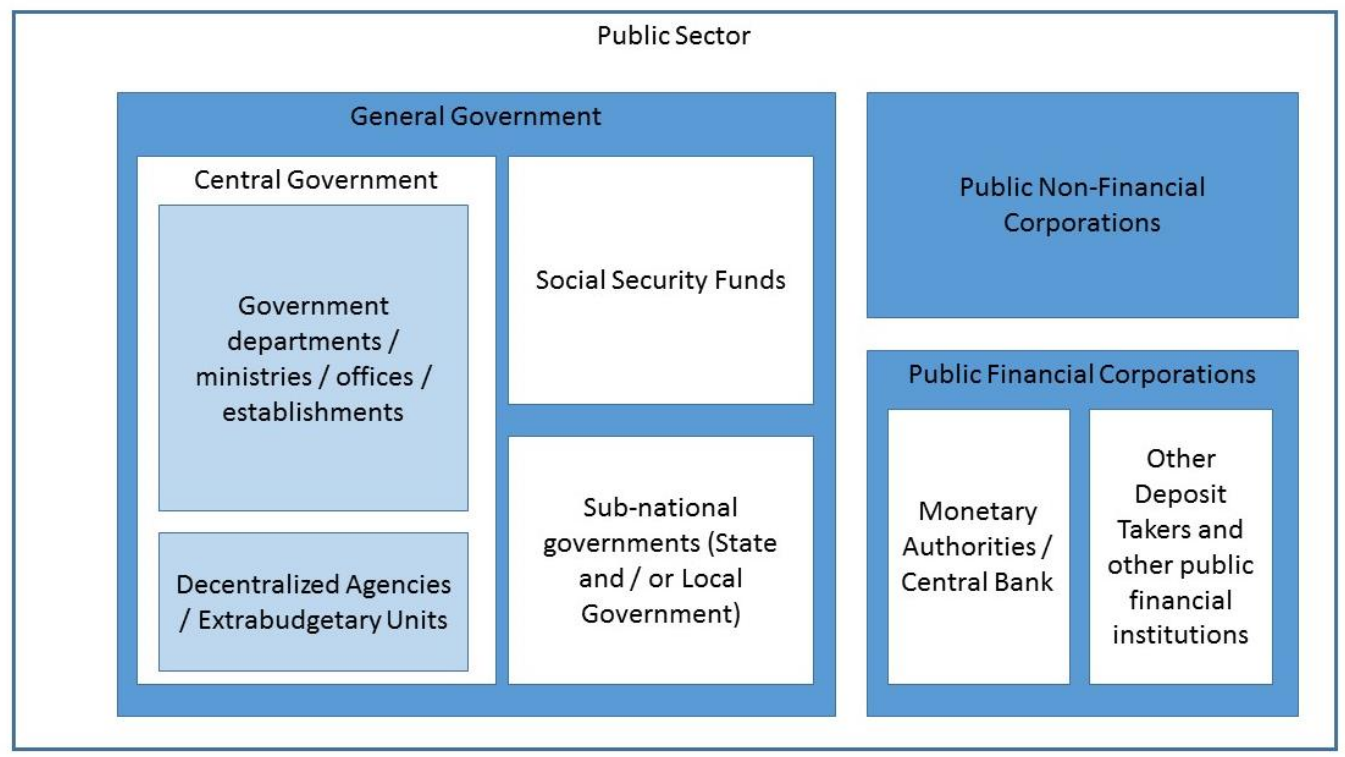

The GFSM 2001/14 2 lays out two key principles to differentiate the public from the private sector, and within the public sector, to distinguish between government units and public corporations.

1. Principle of control. Units are recognized as part of the public sector if they are controlled by the government. This can be as a result of ownership (if a single government unit or multiple government units are the only shareholder in a company, for example), but control can also be exercised through legal, regulatory or other means.

2. Principle of market production. Public units are classified inside the general government sector if they are non-market producers. GFSM $2014 \S 2.65$ states that "A market producer is an institutional unit that provides all or most of its output to others at prices that are economically significant. A nonmarket producer provides all or most of its output to others for free or at prices that are not economically significant".

Because market production is in practice harder to establish than government control, GFSM provides a quantitative market test for nonfinancial units. GFSM $\$ 2.69-75$

\footnotetext{
${ }^{2}$ Definitions and principles within the public sector have now been harmonized between GFSM 2001/14 Chapter 2 and SNA 2008 Chapter 4. However, GFSM 86 already recognized that the definition of government could include units legally established as corporations, and was not simply limited to ministries, government departments, municipalities, law enforcement and judicial entities and other more obvious parts of government. See chapter I of GFSM 1986.
} 
defines a test for classifying public units engaged in nonfinancial activities as market producers in which sales must exceed 50 percent of production costs. ${ }^{3}$ Special scrutiny applies to units that sell only to government, or that are monopoly suppliers (See Box 1 for an application).

Public units engaged in financial activities are harder to classify still and require an analysis of their functions. Classification of the Central Bank, arguably a non-market producer, outside general government is a result of a long-standing convention to treat the Central Bank as part of the financial corporations sector. A key question for other public units engaged in financial activities is often the extent to which a unit is engaged in financial intermediation, lending to and borrowing from the public at large or large groups thereof. At the borderline, the distinction between a public unit engaged in financial activities and a government unit, can become blurred. GFSM 2014 has included more guidance in this area but guidance is continuing to evolve.

These rules and guidance imply that public units that are heavily reliant on government subsidies, grants, guarantees, or other financial support, rather than payments by the end users should be considered non-market units and classified inside general government. In the European Union, where this boundary is most heavily scrutinized and enforced, a number of countries have revised their government boundary to include a wide range of units such as export banks, development banks, deposit protection funds and other units previously not included in their GFS data reported to the EU.

The IMF encourages use of general government, and this is probably the most widely used and available measure. However, although general government data can be found in around 40 per cent of all staff reports 4 including most advanced economies, IMF surveillance frequently takes place using a different sectoral coverage. The GFS Manuals recognize that fiscal analysis can take place at different levels. For example, in less developed countries it is not atypical for surveillance to cover the budgetary central government only, due to lack of data for the wider general government. In some parts of the world, but particularly Latin America, the boundary often extends to the nonfinancial public sector or total public sector. Examples of this practice are: (i) Brazil (data includes the Central Bank and some public nonfinancial enterprises), (ii) Mexico (data covers state owned enterprises and development banks), and (iii) Mongolia (data covers the development bank).

In China, the perimeter of the government used by the authorities for their official fiscal statistics is narrower than general government. China has an extensive public sector, with thousands of State Owned Enterprises (SOEs), majority publicly owned retail and policy banks, provincial and local level special purpose vehicles and corporate entities

\footnotetext{
${ }^{3}$ Eurostat's Manual on Government Deficit and Debt section I.2.4.3 further elaborates on this test.

4 The 2017 Board paper "Second Review of the Implementation of Government Finance Statistics Framework to Strengthen Fiscal Analysis" found that 67 staff reports use General Government, 85 used central government or budgetary CG, 18 used a wider measure than general government.
}

(continued...) 
among many others. Some of these units are very likely not market producers. And yet, Chinese fiscal data includes no extra-budgetary unit, and doesn't even fully consolidate budgetary units. ${ }^{5}$ Therefore, China's definition of government does not include units that would be included inside general government by most other large economies. The coverage of official Chinese fiscal data is shown in Figure 2.

Figure 2. Public Sector Coverage in China's Official Fiscal Statistics

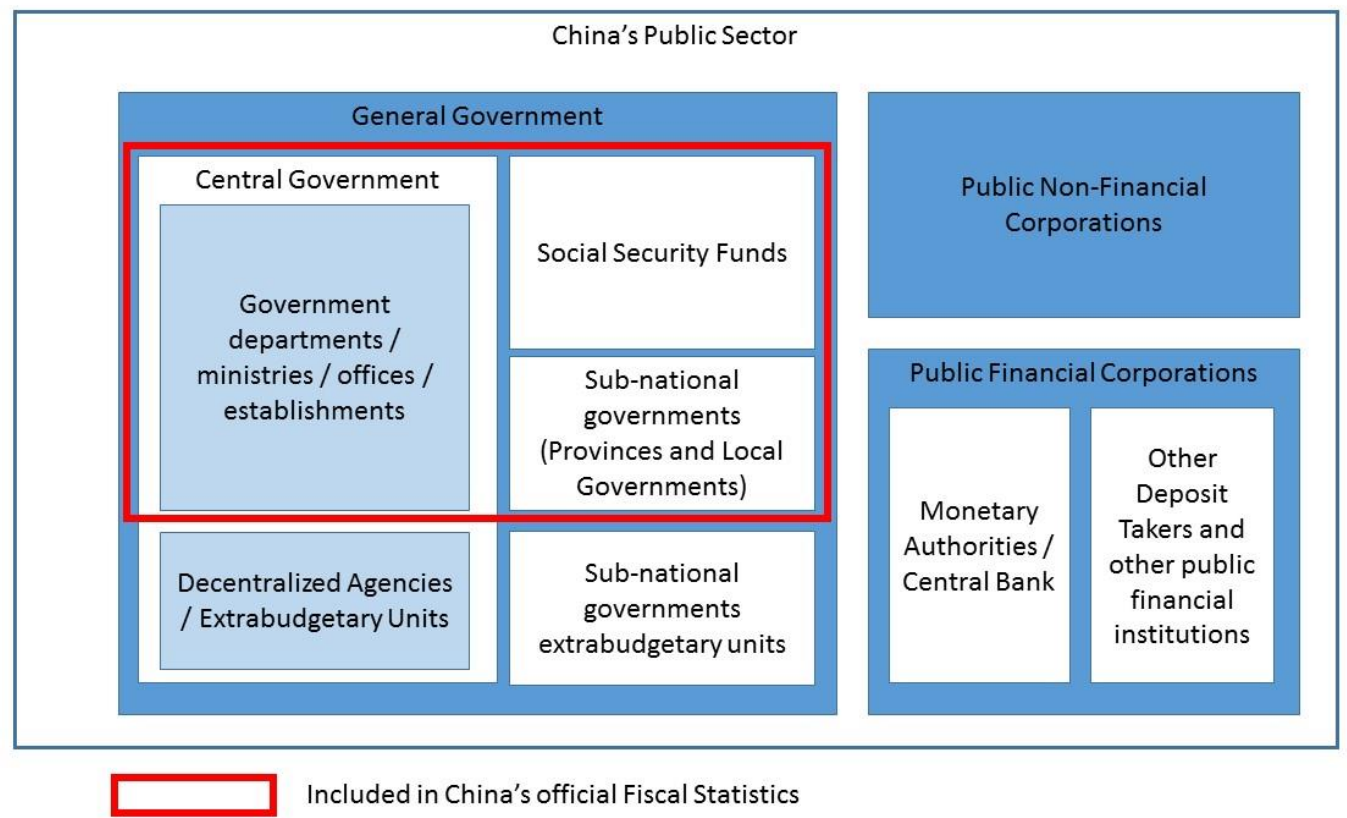

III. REVISITING AUGMENTED GOVERNMENT ESTIMATES

In the recent past, the Chinese government implemented large-scale fiscal stimulus through off-budget vehicles ${ }^{6}$, prompting IMF staff to create the concept of "augmented" balance and "augmented" debt. ${ }^{7}$ These LGFVs appeared as a natural way to bypass the strict constraints on borrowing, which effectively barred local governments from borrowing.

\section{Since 2014, the authorities took significant measures to bring spending on-budget,} recognize past off-budget debt, and allow more government bond issuance ("open the

\footnotetext{
${ }^{5}$ The national budget document includes 4 main types of units: (i) general public budgets, for both central and sub-national governments; (ii) social security funds; (iii) government managed funds and (iv) state capital funds. The Chinese authorities only consider the consolidated deficit of the general public budgets when referring to general government deficits.

${ }^{6}$ See Bai and others (2016) for a comprehensive discussion of the off-budget stimulus undertaken in 2009-10

${ }^{7}$ See Zhang and Barnett (2014) for the original estimates and discussion.
}

(continued...) 
front door") while limiting new off-budget activities ("close the back door"). The authorities issued several important documents:

- New budget law (August 2014), effective in January 2015 sets out broad goals. ${ }^{8}$

- State Council document 43 (September 2014) operationalizes the new budget law. ${ }^{9}$

- State Council document 88 (November 2016), creates a resolution framework that categorizes Local Government (LG) units by risk level and sets corrective measures.

- Joint circular 50 (April 2017) tightens the ban on off-budget borrowing and urges local governments to thoroughly inspect financing activities and correct illegal behavior by July 2017.

- Joint circular 62 (May 2017) clarifies the issuance of local government special purpose bonds under government managed funds.

- Document 87 (May 2017) prohibits financing of projects through build-transfer schemes.

As a result, the front door opened and on-budget LG deficits and debt expanded. LG on-budget net borrowing rose from 0.3 percent of GDP in 2014 to 2.4 in $2016,{ }^{10}$ and, in same period, LG bond issuance expanded from 0.5 to 1.2 percent of GDP (see figure 3).

The authorities also recognized 22 percent of GDP worth of legacy LGFV debt and announced a swap for LG bonds in 2014. Prior to 2014, official LG debt only included residual bonds issued by

Figure 3. Financing of LG spending (percent of GDP)

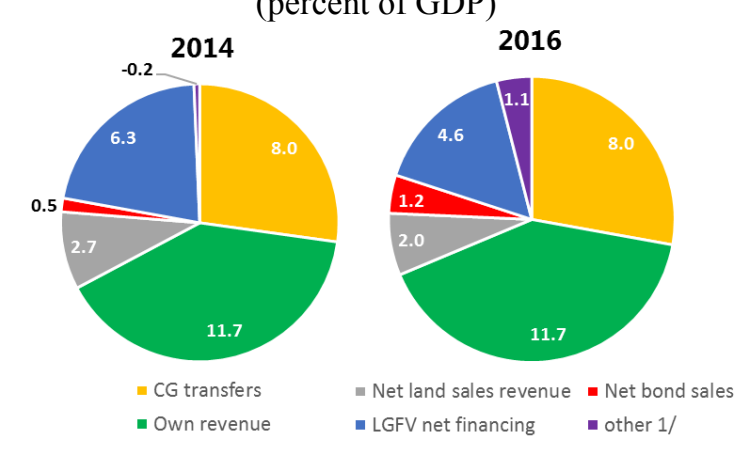

1/ Includes use of carry over and other unused funds from previous years. Sources: Various budget documents, staff estimates. the CG on behalf of LGs. This changed in 2014 with a massive recognition of LGFV debt, most of it shorter-term high-yielding debt. The authorities announced a plan to exchange this legacy debt for new LG bonds with longer maturity and lower yields.

The swap is progressing steadily, although unevenly across provinces. As of June 2017, about $3 / 4$ of the target for LG bond issuance under the swap was completed (see figure $4 \mathrm{a}$ ) and the swap is expected to be completed in mid-2018. There is a wide disparity in the uptake of the swap across provinces, with several provinces yet to reach 50 percent by end-2016 (see figure $4 b)$.

\footnotetext{
${ }^{8}$ See Lam and others (2017) for a thorough discussion of the budget law.

${ }^{9}$ The initial thrust was somewhat scaled back when Document 43 was amended in May 2015.

${ }^{10}$ After deducting central government transfers and land sales revenue but before bond/cash financing.
} 
Figure 4a. Stock of outstanding local government bonds for swap purposes

(In trillion RMB)



Figure 4b. Ratio of bonds for swap purposes outstanding in 2016 to total debt in 2014 1/ (Percent)

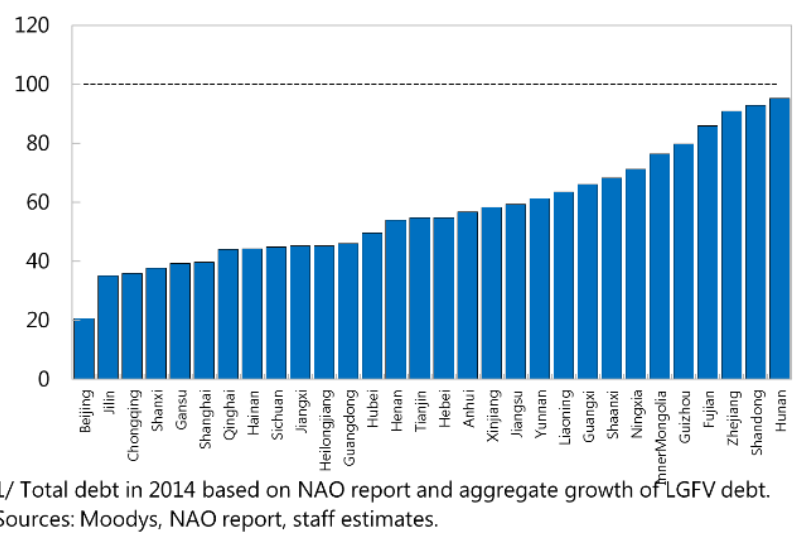

Despite considerable efforts, the back door remains open through three main channels. The traditional channel, through LGFVs is considered first. But two other channels have emerged, PPPs and government funds. See figure 5 for a diagram of the 3 channels to fund infrastructure spending.

Figure 5. Financing channels for infrastructure spending

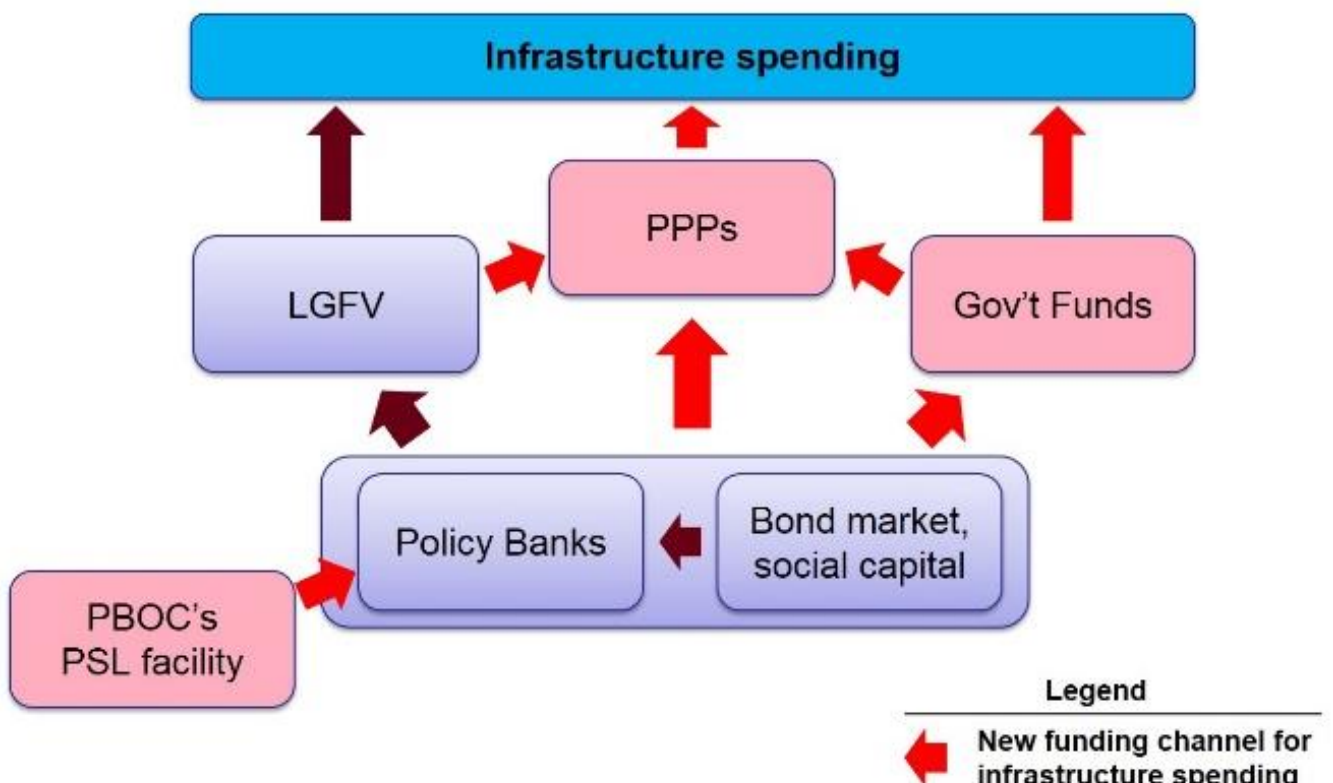

\section{Channel 1: LGFVs}

LGFVs borrowed extensively in 2016 and market perceptions of their implicit guarantee do not seem to have changed substantially since the new budget law, though this could be changing with the recent tightening of financial conditions. In the onshore 
market, LGFV bond spreads declined continuously up to November 2016, even after the new budget law was implemented (see figure 6a). In the offshore market, international rating agencies continue to factor-in government support in LGFV ratings (figure 6b). However, since late 2016, financial conditions in onshore markets have tightened considerably. LGFVs have seen decreased issuance and higher spreads, particularly for lower rated LGFVs. This could be an indication that perceptions are beginning to change, although LGFV yields receded slightly in April-May and thus it is still too early to judge.

Figure 6a. Bond spreads over treasury bonds at 5 year tenor (percentage points)

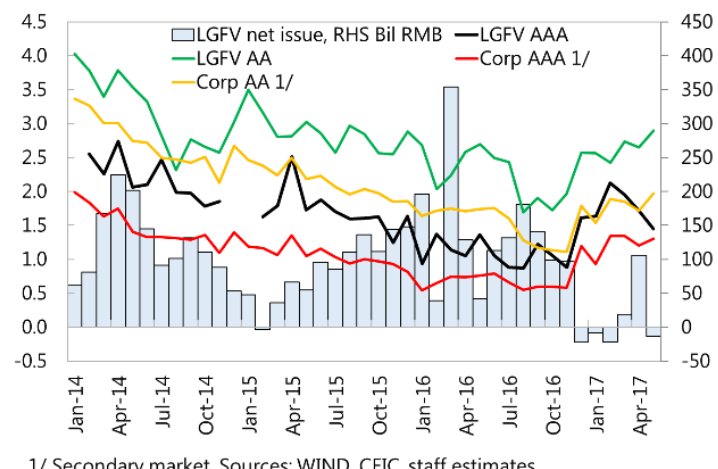

Moreover, the swap may be allowing LGFVs to borrow more. The main objectives of the swap were to reduce the interest burden and lengthen the maturity structure of LG debt. While interest payments have fallen due to the interest differential between LGFV debt and LG bonds, LGFV debt continues to grow rapidly including short-term higher-yielding debt (see figure 7). This increase in debt cannot be explained by a timing discrepancy between when LGFVs receive swap proceeds and pay down debt as liabilities net of cash are also rising.
Figure 6b. Implicit support of LGFV offshore issuance

(uplift in ratings, notches)

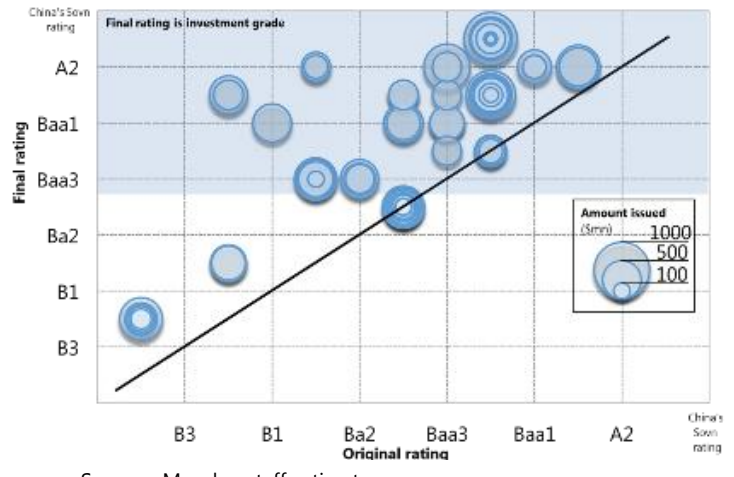

Sources: Moodys, staff estimates.

\section{Figure 7. Liabilities of LGFVs that have issued} bonds 1/

(trillion RMB)



\section{Channel 2: PPPs}

PPPs are meant to replace the LGFV model but the difference may be only superficial. The capital value of PPP projects is significant at 27 percent of GDP by end-2016, with 1/5 under implementation. Although, PPPs are meant to substitute the LGFV model by utilizing financing from and shifting risk to the private sector, most PPPs are concentrated in 
traditional public infrastructure areas (more than 80 percent) and the PPP partner is often state-controlled (solely private partners make up around 30 percent of investment ${ }^{11}$ ). Partners can range from policy banks, government funds, private capital to other state-owned parties, like central and local SOEs and even LGFVs. Moreover, PPPs appear to be most used where augmented debt is largest, raising the possibility that PPPs are being used to circumvent borrowing limits and hide fiscal spending (figures 8a-8d).

Despite several positive improvements, the regulatory framework for PPPs still lags international best practice. PPPs in China are governed by three regulatory framework documents rather than a single law; there is insufficient weight given to value for money considerations either before contracts or awarded or during the contract period and both accounting and reporting of PPP contracts could be improved.

Figure 8a. PPP pipeline (percent of GDP)

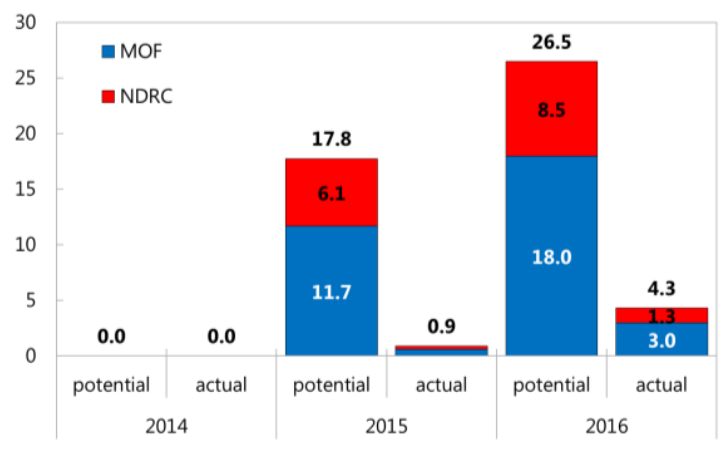

Sources: MoF PP center, news, staff estimates.

Figure 8c. PPP investment is concentrated in traditional public infra areas $1 /$ (percent)

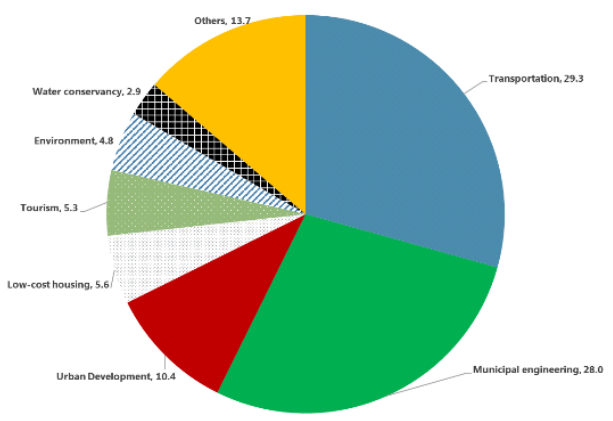

1/ Including only investment in demonstrations projects. Source: China PPP center, staff estimates
Figure 8b. PPP partner is often state-owned 1/ (percent)



1/ Including only investment in demonstrations projects. Source: China PPP center, staff estimates

Figure 8d. PPP pipeline vs LG/LGFV debt in 2016 (percent of GDP)



Sources: Wind, CBONDS, news sources, CEIC, PPP center and staff estimates.

\footnotetext{
${ }^{11}$ Data for demonstration projects as of Dec-2016 available at http://www.cpppc.org/en/Quarterly/4778.jhtml.
} 


\section{Channel 3: leveraged government funds}

The authorities are increasingly setting up Government Guided Funds (GGFs) and Special Construction Funds (SCFs) to fund public infrastructure. These new financing vehicles are akin to public venture capital funds which are unusual in an international context. GGFs are funded by a mixture of budgetary (a "junior tranche") and nonbudgetary contributions (a "senior tranche" delivering a steady return) called "social capital", which includes contributions by SOEs, LGFVs, banks or other financial institutions. SCFs are entirely funded by policy banks. GGFs and SCFs are still raising capital, with end-2016 assets of around 5 percent of GDP (figure 9). Detailed information on their activities is not available, but these funds are likely investing in equity

Figure 9. Gov't Guided and Special Construction Funds

(assets, percent of GDP)

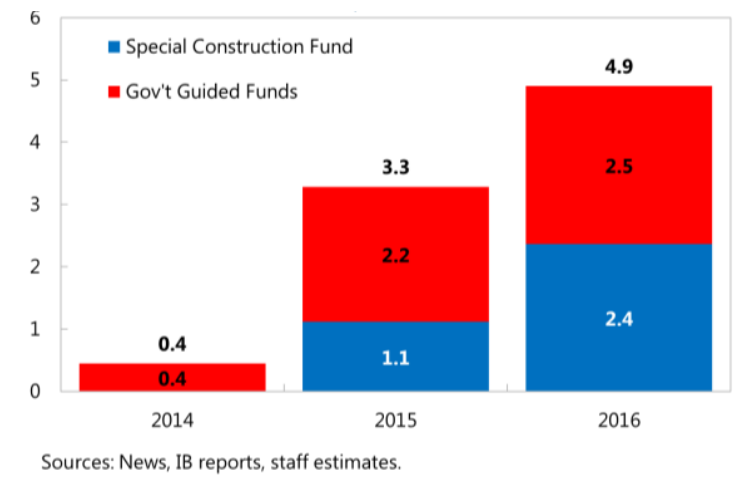
stakes of PPPs or firms, and also lending.

\section{Implications for the perimeter of government}

Available evidence suggests LGFVs continue to operate as quasi-fiscal units and thus their activities should continue to be included in estimates of augmented balance and debt until a careful case-by-case analysis is completed. See Box 1 on LGFV classification.

\section{Box 1: Are LGFVs market or non-market producers?}

GFSM 2014 provides guidance on how to determine whether a nonfinancial unit is a market or non-market producer. In most cases this is done by comparing receipts from sales and the production costs of the goods and services sold, i.e. the so called "market test".

Units where sales cover at least half the production costs over a multi-year period are generally classified as market producers, and hence as nonfinancial public corporations. The definition of sales is not the same as total revenue, or operating revenue. Sales exclude government transfers and subsidies (if these are not available to other producers operating in the same industry), they also exclude revenue that has the nature of a tax, or an administrative fee and property incomes like interest or rent of a nonproduced asset.

While this essentially quantitative test can be carried out with access to financial statements of most companies, GFSM 2014 provides additional guidance when making classification decisions. These additional criteria are highly relevant for China's LGFVs: 
- Government support is important. GFSM $2014^{12}$ notes that corporations receiving substantial government financial support or other risk reducing factors such as guarantees are more likely to be classified as non-market producers.

- Sales to government and competition are important. GFSM $2014^{13}$ notes that units that provide goods and services to other government units, in the absence of competition from private providers or when government purchase decisions aren't based on price, are likely to be non-market producers.

These two additional pieces of guidance are highly relevant for many LGFVs. LGFVs receive considerable government support often including government guarantees on their debt, direct financial support in the form of transfers and subsidies and asset transfers, especially land. In addition, sales by LGFVs are often dominated by sales to their parent municipality who commission new infrastructure, without a competitive process.

These two factors may mean that, while a superficial analysis may conclude that some LGFVs are market units, a more in depth analysis would likely conclude that a majority of LGFVs are non-market units that should rightly be classified inside general government.

Determining whether LGFVs are non-market producers though would require a careful case-by-case review of their activities. This task cannot be conducted in the absence of necessary information that is not publicly available. According to the last audit with publicly announced results, there were more than 7,000 LGFVs alone in June-2013. There is no evidence to suggest that number has come down. Most LGFVs don't publish financial accounts to the best of our knowledge and only local governments would have access to the necessary information.

Two individual LGFVs are examined in more detail in Appendix 1, and some of the challenges in classifying these types of units are discussed.

Given the new channels for infrastructure investment in the form of PPPs and leveraged government funds, expanding the perimeter of augmented fiscal aggregates is warranted.

- There is a strong case for including government funds in augmented fiscal accounts ("Augmented +"). Following the guidelines for sector classification in the Government

${ }^{12}$ GFSM $2014 \S 2.71$.

${ }^{13}$ GFSM $2014 \S 2.72$ 
Finance Statistics Manual GFSM 2014, staff concludes that these funds are likely to be general government units based on government control and non-market nature of activities. These funds should be regarded as public sector units since the government National Development and Reform Commission, Ministry of Finance or local governments - retains control (even if the government is a minority shareholder ${ }^{14}$ ). Moreover, the funds do not appear to make market-based decisions in pursuit of commercial returns and openly serve a social function. Thus, staff concludes they should be included in government. ${ }^{15}$ Appendix 2 details sources, data and assumptions made.

- While, some of China's PPPs should in principle be recorded on-balance sheet ${ }^{16}$, estimates are highly uncertain. Including government-funded PPPs expands the augmented balance ("Augmented++") only marginally as most PPPs are yet to be implemented. These estimates are very uncertain due to insufficient granularity of published data on PPPs.

Considering the tradeoffs, staff included GGFs and SCFs in augmented aggregates ("augmented+"), but not PPPs, and finds that China's fiscal stance is more expansionary than previously thought (figure 10). China's "augmented+" deficit reached 12.4 percent of GDP in 2016 from 9.8 in 2014. Under the previous definition of augmented balance (including only LGFVs), the deficit expanded only marginally to 10.3 in the same period (text chart). Given the uncertainties regarding PPPs, staff is not including those for now in augmented deficit/debt ("Augmented +"). PPPs may be included in the future depending on data availability.

Figure 10. Augmented government balance: different definitions

(In percent of GDP)

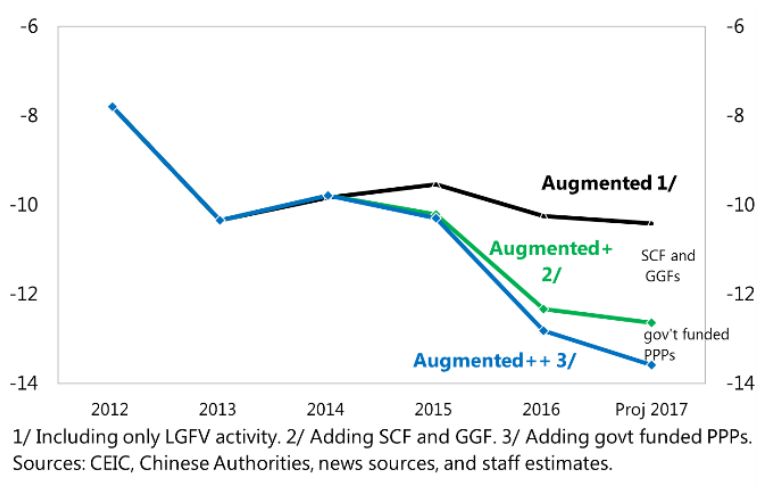

Even after expanding the perimeter of augmented aggregates, all of the expansion of China's fiscal stance in 2014-16 was on-budget. On-budget net borrowing expanded by $23 / 4$ p.p. of GDP in 2014-2016, meaning off-budget activities are estimated to have remained broadly unchanged - though still at an elevated level -- after expanding the perimeter of augmented aggregates.

There are other channels not included in augmented aggregates that may be quasi-fiscal in nature, most importantly policy bank activities. The Agricultural Development Bank of

\footnotetext{
${ }^{14}$ Interim Measures for the administration of government investment funds (November 2015), Ministry of Finance.

15 The treatment of social capital contributions as debt is based on GFSM 2014 7.143, 7.150 and 7.166.

${ }^{16}$ See GFSM 2014 Appendix 4, paragraphs A4.58-65 and IPSAS 32 on “Service Concession Arrangements".
} 
China (ADBC) and China Development Bank (CDB) have long funded LGFVs (Ma, 2012), and are now increasingly financing large-scale PPPs and government funds. They are large (combined assets of 24 percent of GDP in 2015) and growing fast (estimated asset growth of 24 percent in 2016, vs. system asset growth of 17 percent). Much of their operations are still opaque, making it hard to estimate the extent of their quasi-fiscal activity. The CDB has been lending increasingly under the so called "shanty town renovation program" whereby funds are used to develop shantytown urban areas and to compensate displaced residents. By end2016 CDB's outstanding loans for this program were 2.3 percent of GDP up from virtually zero in 2014. Such activities fulfill a national development goal and are likely to have substantial implicit subsidies components, and also overlap with other components already captured in the Augmented deficit, such funding of LFGVs and government-guided funds.

\section{CONCLUSIONS AND POLICY IMPLICATIONS}

The authorities took positive steps to stem the proliferation of off-budget borrowing in the last two years. The budget law brought more clarity to the budgeting process and made it more encompassing. LGs are now borrowing on-budget and have increased on-budget spending. Subsequent regulations gave provincial governments the responsibility to monitor lower-level LG units and created a framework for assessing risk and resolving problem cases. Legal actions against non-complying units have taken place. In early May, the authorities issued a notice that bans LG off-budget borrowing through offering a minimal return on PPPs or funds, creating proxy private vehicles to borrow or providing guarantees. ${ }^{17}$ The notice also mandates a full review of government guarantees by July 2017, although results are not yet public. All these developments are welcome and show the authorities' resolve to deal with rapidly growing off-budget debt, although policy implementation continues to be a challenge.

\section{Despite this positive reform progress, LGFVs and the new channels via GGFs, SCFs and PPPs, continue to provide mechanisms for off-budget government investment. Consequently, staff argue that augmented fiscal aggregates remain relevant for measuring quasi-fiscal activity, and finds that their perimeter should even be extended beyond LGFVs to include new investment channels through GGFs and SCFs. PPPs are not included due to lack of granular data that is required to evaluate their fiscal implications.}

\section{A longer-term solution to the classification and control of government accounts would include improving the delineation of general government and enhanced data collection by the authorities:}

- Establish a dedicated classifications team: Given the size and complexity of the Chinese economy, and the number of institutional units, a dedicated crossdepartmental team which could include NBS, MoF, PBOC, CBRC among others, should be established. Such a team would systematically evaluate public sector units

\footnotetext{
${ }^{17}$ Joint notice by the MOF, NDRC, PBOC, CBRC, CSRC and Ministry of Justice issued in May 32017.
} 
and judge their inclusion in general government according to current international statistical guidelines such as GFSM 2014. The outcome of this work would be a list of general government units in China to be used for all macroeconomic statistics.

- Prioritize classification of significant units: initial efforts should be focused on units or groups of units with higher levels of revenue, expenditure or debt and analysis carried out at a sufficiently detailed level. The classifications team should have the clear authority to request necessary data and answers to follow up questions.

- Integrate statistical classifications into the policy process: ministries should be encouraged to seek guidance on the classification of new units or novel transactions ahead of policy being finalized.

- Comprehensive GFS Reporting: China should move toward compilation of comprehensive GFS and National Accounts sectoral reporting, both for reporting to the IMF and domestic use.

\section{Additionally, the fiscal framework can be further improved in key areas:}

- $\quad$ Planning: Formulate a medium-term fiscal framework, including a medium-term integrated capital financing plan with public investment priorities and financing needs. Create an incentive system for LG units using a combination of carrots (bond quotas, expedited approval of infrastructure projects) and sticks (enforcement, legal actions)

- $\quad$ Monitoring: Increase capacity and resources at the provincial government level for effective monitoring of lower level units. Crucially, enlarge the perimeter of monitoring - as done in past NAO reports -- to encompass contingent liabilities from PPPs, funds and LGFVs. Monitoring of contingent liabilities should not be viewed as an unconditional recognition of those liabilities or underlying expenses.

- $\quad$ Transparency: The authorities should publish detailed and easily accessible budget accounts and overall debt levels by province at least yearly, including contingent liabilities by type. Medium-term fiscal projections and an assessment of the riskiness of broadly defined public debt by province or even district could also be published regularly.

\section{Recording, planning, and monitoring of new financing channels should be a priority:}

- $\quad$ Special construction and guided funds: These are not well covered as they are deemed outside of government, but also not under the purview of financial sector regulators. MoF should have full authority. SCF and GGFs should be required to provide reports to sponsoring government units, which would then report to the MOF. Reports should cover balance sheets (assets, liabilities and capital holders) and income statements 
(return to investment, interest / dividends). Such data should be included in government accounts and made public.

- $\quad$ PPPs: The four-pillar approach of Jin and Rial (2016) provides a comprehensive compilation of best practices. It includes (i) integration of planning with budget and investment plans; (ii) a strong institutional framework, PPP center as a "one-stopshop" coordinating MoF and NDRC efforts; (iii) a single PPP framework law; and (iv) appropriate accounting and reporting practices, treating PPPs on-budget per international guidelines. A gradual implementation strategy could follow their recommendations. ${ }^{18}$

- Quasi-fiscal activities of policy banks: Policy bank investment in and lending to PPPs, LGFVs, GGFs and SOEs, should be clearly disclosed in the policy banks' annual reports.

${ }^{18}$ See Section V of Jin and Rial (2016). 


\section{REFERENCES}

Bai, C., C.-T. Hsieh, and Z. M. Song, 2016, “The Long Shadow of a Fiscal Expansion”, NBER Working Paper 22801.

GFSM, 1986, 2001, 2014, "Manual on Government Finance Statistics,” IMF.

IMF, 2013, "People's Republic of China Staff Report for the 2013 Article IV consultation"

Jin, H., and I. Rial, 2016, "Regulating Local Government Financing Vehicles and Public-Private Partnerships in China," IMF Working Paper 16/187

Lam, W. R., J. Wei, and H. van Eden (2017), "Local Government Finances and Fiscal Risks" in Modernizing China: Investing in soft infrastructure, edited by R. Lam, M. Rodlauer, and A. Schipke.

Ma, H., 2012, "Research on the Development of Local Government's Investment and Funding Corporations," Central University of Finance and Economics and Pengyuan Credit Rating Corporation (China Financial Economics Press).

National Audit Report, 2011, “Audit Findings on China’s Local Government Debts,” No.35, General Serial No. 104.

National Audit Report, 2013, “Audit Results on Government Debt of 36 Local Governments," No.24, General Serial No. 166.

Zhang, S. and S. Barnett, 2014, "Fiscal Vulnerabilities and Risks from Local Government Finance in China," IMF Working Paper 14/4 


\section{ApPendix 1: CASE Studies - Classification of Selected LGFVs}

\section{A. Tianjin Rail Transit Group Ltd}

Tainjin Rail Transit Group (TRTG) is a wholly state owned subsidiary of the Tianjin Stateowned Assets Supervision and Administration Commission of Tianjin Municipal People's Government, and was established in 1992. The group is described as "the sole investment and financing platform for the rail transit system in Tianjin and responsible for the investment, construction, operation, management and maintenance of rail transit system and rail transit stations in the Tianjin area, as well as the integrated development of the land and property along the rail transit lines."

In 2015 the group had operating revenue of RMB 2.3bn, total assets of RMB $231 \mathrm{bn}(0.33 \%$ of GDP) and total liabilities of RMB $122 \mathrm{bn}(0.17 \%$ of GDP).

While TRTG is clearly a public sector unit, should TRTG be considered to be a general nonmarket units classified inside the general government sector, or a market producer classified outside as a public nonfinancial corporation? To determine whether a unit is a market producer, GFSM 2014 requires that a unit charge economically significant prices (see GFSM 2014 \$2.66), and that the value of sales to average at least half of the production costs over a sustained multiyear period (GFSM 2014 §2.69). Both sales and production costs have specific definitions in GFSM. Sales exclude all payments receivable from government unless they would be granted to any producer undertaking the same activity, for example.

Production costs include compensation of employees, use of goods and services, consumption of fixed capital, and other taxes on production, as well as costs of capital (often proxied with net interest costs).

In the case of TRTG, detailed financial information provided as part of the groups issuance of bonds in 2016 included detailed financial information for 2013 -2015. The summary consolidated income statement of the company showed the following:

Table 1: Consolidated income statement of TRTG

\begin{tabular}{|l|l|c|c|c|}
\hline & & $\mathbf{2 0 1 3}$ & $\mathbf{2 0 1 4}$ & $\mathbf{2 0 1 5}$ \\
\hline A & Total Operating Revenue & $\mathbf{2 , 3 6 7 . 6}$ & $\mathbf{2 , 4 1 9 . 0}$ & $\mathbf{2 , 3 7 9 . 3}$ \\
\hline B & Total Operating Cost & $\mathbf{2 9 7 2 . 8}$ & $\mathbf{2 9 8 4 . 8}$ & $\mathbf{3 , 4 3 0 . 0}$ \\
\hline C & Including Operating Cost & $2,019.1$ & $2,391.9$ & $2,626.2$ \\
\hline D & Business tax and surcharge & 98.9 & 83.2 & 117.3 \\
\hline E & Sales expenses & 21.0 & 19.7 & 27.3 \\
\hline F & Administrative expenses & 388.8 & 474.4 & 534.3 \\
\hline G & Financial expenses & 442.6 & 9.8 & 119.9 \\
\hline H & Interest expenses & 550.0 & 41.7 & 149.9 \\
\hline I & Interest income & 129.2 & 38.8 & 52.5 \\
\hline J & Net losses on f/x transactions & 8.7 & $(13.6)$ & $(6.3)$ \\
\hline K & Asset impairment losses & 2.4 & 5.8 & 4.9 \\
\hline L & Add gains from change in fair value & 196.4 & 149.5 & 94.7 \\
\hline
\end{tabular}




\begin{tabular}{|l|l|c|c|c|}
\hline M & Operational Profit (Loss) & $\mathbf{( 3 4 9 . 9 )}$ & $\mathbf{( 3 5 8 . 2 )}$ & $\mathbf{( 8 7 2 . 2 )}$ \\
\hline N & Add: Non-operating revenue & $1,109.9$ & 870.9 & $1,342.8$ \\
\hline O & $\begin{array}{l}\text { Of which: government grants and } \\
\text { subsidies }\end{array}$ & $1,099.3$ & 861.8 & $1,124.4$ \\
\hline P & Less: Non-Operating expenses & 9.3 & 26.7 & 5.8 \\
\hline Q & Profit before tax (loss) & $\mathbf{7 5 0 . 7}$ & $\mathbf{4 8 6 . 0}$ & $\mathbf{4 6 4 . 8}$ \\
\hline
\end{tabular}

Source: TRTG Offering Circular, 4 May 2016

The TRTG data shows that operating losses in all three years were turned into overall profits before tax as a result of considerable government financial support (Row O). The market test results for TRTG taking this high-level data are as follows:

Table 2: A high-level market test of TRTG

\begin{tabular}{|l|l|c|c|c|}
\hline & & $\mathbf{2 0 1 3}$ & $\mathbf{2 0 1 4}$ & $\mathbf{2 0 1 5}$ \\
\hline $\mathrm{R}$ & Sales $=\mathrm{A}$ & $2,367.6$ & $2,419.0$ & $2,379.3$ \\
\hline $\mathrm{S}$ & Production Costs $=\mathrm{C}+\mathrm{D}+\mathrm{E}+\mathrm{F}+\mathrm{G}+\mathrm{P}$ & $2,979.70$ & $3,005.70$ & $3,430.80$ \\
\hline $\mathrm{T}$ & Market Test $=\mathrm{R} / \mathrm{S}$ & $79.5 \%$ & $80.5 \%$ & $69.4 \%$ \\
\hline
\end{tabular}

Source: Staff Calculations

To determine whether TRTG is a market unit, a more detailed explanation of the nature and source of operating revenue is needed. It is not clear whether all operating revenue should be considered "sales" for the purposes of the market test. Note 37 to the audited financial statements for the year ending 31 December 2015 includes more information on the operating revenue. The two largest components are metro operating revenue, (which comprises about $26 \%$ of total operating revenue in 2015) and "gains from settlement of projects" (which accounts for $59 \%$ of operating revenue). While it is reasonably clear that metro operating revenue (likely to consist of fares paid by users of the system) would be sales, its far less clear what "gains from settlement of projects" represents. If this item does represent sales at economically significant prices, then TRTG is likely to be a market producer and classified outside the government sector, but if it is not sales, but something else, then TRTG should probably be classified as a non-market producer and classified inside general government, meaning its debt would be added to general government.

GFSM 2014 requires that close attention be paid to transactions with government. Part of what TRTG does is build infrastructure for the city of Tianjin. It is not at all clear whether it does this in competition with private producers, though this seems very unlikely, but applying the guidance at GFSM 2014 §2.72, it would at least raise questions as to whether a lack of competition for some services that TRTG carries out precludes treating revenue from these activities as "sales" when applying the market test.

\section{B. Zhenjiang Transportation Industry Group Co Ltd.}

Zhenjiang Transportation Industry Group Co Ltd (ZTIG) is controlled by the Zhenjiang State-owned Assets Supervision and Administration Commission of Zhenjiang Municipal 
People's Government, and was established in 1992. The group is described as "the primary investment and financing platform of the Zhenjiang municipal government focusing on the development and construction of transportation infrastructure within Zhenjiang." It is also described as "one of four local government financing platforms established by the Zhenjian municipal government for the purposes of financing capital intensive public interest projects". This doesn't tell the whole story however. ZTIG's financial statements also explain that the business scope of the company includes "investment in and construction of road traffic construction projects and development of supporting projects; technical advice on transport projects; design, production and release of road signs, light boxes, neon lamps, gifts, banners, billboards, samples and brochures, and advertisements at exhibition area; acting as an agent for domestic advertising of the same type as well as advertising on movie and TV; broadcasting, advertising and newspaper advertising business, land consolidation and development; agency management of engineering projects; investment in and construction of water agency projects." Its not clear how big each of these business segments are, but what is clear is that the group has a wide range of activities across many sectors.

In 2015 the group had operating revenue of RMB $2.1 \mathrm{bn}$, total assets of RMB $91 \mathrm{bn}(0.13 \%$ of GDP) and total liabilities of RMB 56bn ( $0.08 \%$ of GDP).

As with TRTG, ZTIG is clearly part of the public sector, but determining whether it should be classified inside the general government sector, or classified as a public nonfinancial corporation outside the general government sector is less straightforward. Detailed financial information provided as part of the groups issuance of bonds in 2016 included detailed financial information for 2013 -2015. The summary consolidated income statement of the company showed the following:

Table 3: Consolidated income stamement of ZTIG

\begin{tabular}{|l|l|c|c|c|}
\hline & & $\mathbf{2 0 1 3}$ & $\mathbf{2 0 1 4}$ & $\mathbf{2 0 1 5}$ \\
\hline A & Total Operating Revenue & $\mathbf{1 , 5 0 0 . 4}$ & $\mathbf{1 , 5 1 3 . 4}$ & $\mathbf{2 , 1 0 7 . 3}$ \\
\hline B & Total Operating Cost & $\mathbf{1 , 2 7 6 . 1}$ & $\mathbf{1 , 5 2 2 . 5}$ & $\mathbf{1 , 9 6 2 . 9}$ \\
\hline C & Including Operating Cost & $1,132.3$ & $1,301.3$ & $1,740.8$ \\
\hline D & Business tax and surcharge & 85.7 & 98.4 & 58.4 \\
\hline E & Selling and distributions expenses & 0.8 & 2.1 & 1.3 \\
\hline F & General and Administrative expense & 55.2 & 113.7 & 158.0 \\
\hline G & Financial expenses & 1.0 & 5.8 & 7.6 \\
\hline H & Losses from asset impairment & 1.2 & 1.2 & $(3.3)$ \\
\hline I & Gains from change in fair value & - & - & $(0.4)$ \\
\hline J & Investment Gains & 18.5 & 7.8 & $(13.5)$ \\
\hline K & Operational Profit (Loss) & $\mathbf{2 4 2 . 7}$ & $\mathbf{( 1 . 3 )}$ & $\mathbf{1 3 0 . 5}$ \\
\hline L & Add: Non-operating revenue & 84.9 & 382.6 & 328.6 \\
\hline M & Less: Non-Operating expenses & 2.9 & 21.5 & 2.8 \\
\hline N & Profit before tax (loss) & 324.7 & 359.7 & 456.3 \\
\hline
\end{tabular}

Source: ZTIG Offering Circular, 19 December 2016 
The ZTIG data made operating profits in two of the three years, and a small operating loss in 2014, but received additional non-operating revenue (Row L) resulting in profits before tax in all three years. The market test results for ZTIG taking this high level data are as follows:

Table 4: A high-level market test of ZTIG

\begin{tabular}{|l|l|c|c|c|}
\hline & & $\mathbf{2 0 1 3}$ & $\mathbf{2 0 1 4}$ & $\mathbf{2 0 1 5}$ \\
\hline $\mathrm{O}$ & Sales $=\mathrm{A}$ & $1,500.40$ & $1,513.40$ & $2,107.30$ \\
\hline $\mathrm{P}$ & Production Costs = C+D+E+F+G+M & $1,277.90$ & $1,542.80$ & $1,968.90$ \\
\hline $\mathrm{Q}$ & Market Test $=\mathrm{O} / \mathrm{P}$ & $117.4 \%$ & $98.1 \%$ & $107.0 \%$ \\
\hline
\end{tabular}

Source: Staff Calculations

As with TRTG, to determine whether ZTIG is really a market unit a more detailed explanation of the nature and source of operating revenue is needed. Note 38 of the 2015 financial statements provides a breakdown of operating revenues across all three years, which are shown in below:

Table 5: Breakdown of operating revenue of ZTIG

\begin{tabular}{|l|l|l|l|}
\hline Components of Operating revenue & $\mathbf{2 0 1 3}$ & $\mathbf{2 0 1 4}$ & $\mathbf{2 0 1 5}$ \\
\hline $\begin{array}{l}\text { Income from transportation related } \\
\text { comprehensive development and operations }\end{array}$ & $1,495.9$ & $1,125.1$ & 402.8 \\
\hline $\begin{array}{l}\text { Income from comprehensive development of } \\
\text { land use right }\end{array}$ & 0 & 261.5 & 369.7 \\
\hline Income from house selling & 0 & 0 & 619.9 \\
\hline Income from sale of goods & 0 & 0 & 465.4 \\
\hline Transportation income & 0 & 110.0 & 86.5 \\
\hline Other operating revenue & 4.4 & 15.6 & 117.5 \\
\hline
\end{tabular}

Source: Notes to the 2015 Financial Statements of ZTIG

This data raises as many questions as the TRTG data. Why have the sources of income changed so dramatically? Who are the customers on the other side of these income streams? To what extent does operating revenue in the various categories listed in the accounts meet the definition of sales in the manual? Without more information, it is impossible to know, but the key figure for the quantitative market test in 2013 and 2014 is the nature of "income from transportation related comprehensive development and operations". If the customer here is the Zhenjiang local government, its highly likely that this revenue would not be considered sales for the purpose of the market test.

\section{Conclusions}

The analysis here of these two LGFV's is, of necessity, only a very high level analysis. Both TRTG and ZTIG, as their names imply, are actually group structures that include a large 
number of companies and subsidiaries. Their audited financial statements are long and complex, with more than 100 pages of detailed explanatory notes.

Despite this level of detail, the accounts do not sufficiently explain the nature of operating revenue, or provide sufficient answers to questions regarding the nature and source of operating revenues. Classifying a unit like these as carried out in other countries would involve an in-depth analysis of business activities, revenue streams and relations with government.

The accounts also make clear, in numerous places, the extent to which the public sector is the dominant customer, a key source of support, benefactor, and key decision maker in the operations of these entities.

The Offering Circulars provide guidance to investors on support provided by government, and risks associated with lending money, to these two LGFVs. Support provided has included financial and nonfinancial support, such as capital injections, government grants and subsidies and debt repayments, asset injections, land use rights and preferential tax treatment. On the risk side, the documents talk about the dependency on government for business, and on the inability to make independent business decisions (for example TRTG warns investors that it cannot choose to raise metro fares to raise additional revenue, since the municipal government controls these), and highlight just how much the business of these companies is linked to public policy.

These two LGFVs are not straightforward market producers, but instead more complex entities, with strong links to their parent municipalities and a range of activities, some of which is likely to be market in nature, but much of it not.

Detailed analysis of these units is required to properly determine the correct classification for both fiscal data and other macroeconomic statistics. 


\section{APPENDIX 2: DETAILED ASSUMPTIONS BEHIND THE INCLUSION OF SCFS AND GGFS}

In the case of SCFs

- $\quad$ Sources: Postal Savings Bank IPO listing in HKEX ${ }^{19}$, Mizuho (2017), Deutsche Bank (2016), BofA Merril Lynch (2016a), news pieces.

- $\quad$ Data: Asset size by year-end, all of it provided by social capital

- $\quad$ Assumptions: Add 10\% of total interest expense to fiscal spending (the other $90 \%$ are already in the budget), this share rises to $30 \%$ as per intention to reduce subsidy component; interest rate $1.5 \%$; disbursements are: $40 \%$ when capital flows in the fund, $60 \%$ following year; projection keeps inflow of capital as a share of GDP constant after 2017

In the case of GGFs

- $\quad$ Sources: Zero2IPO Research, PE daily, Mizuho (2017), BofA Merril Lynch (2016b), news pieces.

- $\quad$ Data: Asset size by year-end.

- $\quad$ Assumptions: Government share of capital inflow declines gradually from 40 percent in 2014 to $20 \%$ in 2016 and onwards; interest rate 7\%; disbursements are slower: $30 \%$ when capital flows in the fund, $40 \%$ following year and $30 \%$ after two years; equity contribution of the government is netted out as it is presumed to be already in the budget although that couldn't be confirmed.

\section{References}

Bank of America Merrill Lynch, 2016a, "Special Construction Fund, a sign of rising stress in the growth model," April 1.

Bank of America Merrill Lynch, 2016b, "Government-Sponsored Industry Fund: new bottle, old wine," February 21.

Deutsche Bank, 2016, “China Financial Daily,” October 10, reporting news from Caixin.

Mizuho Securities Asia Ltd, 2017, "China's hidden fiscal expenditure: Government Guiding Funds and the Special Construction Fund," March 8.

\footnotetext{
${ }^{19}$ http://www.hkexnews.hk/listedco/listconews/SEHK/2016/0914/LTN20160914011.pdf
} 